\title{
Sweet trap: Boa constrictor (Serpentes: Boidae) preying on passerines on Cecropia pachystachya (Urticales: Cecropiaceae) in fruiting period
}

\author{
Gilson da Rocha-Santos ${ }^{1,3}$, Eder Barbier ${ }^{1}$ \& Marcelo Oscar Bordignon ${ }^{2}$ \\ ${ }^{1}$ Programa de Pós-Graduação em Biologia Animal - Universidade Federal de Mato Grosso do Sul - UFMS \\ - Av. Costa e Silva, s/n, Caixa Postal 549, CEP 79070-900, Campo Grande, MS, Brasil. (http://www. \\ bioanimal.ufms. br) \\ ${ }^{2}$ Centro de Ciências Biológicas e da Saúde - Universidade Federal de Mato Grosso do Sul - UFMS - Av. \\ Costa e Silva, s/n, Caixa Postal 549, CEP 79070-900, Campo Grande, MS, Brasil. (http://www.ufms.br) \\ ${ }^{3}$ Corresponding author: e-mail: gilsonsantos.bio@gmail.com
}

ROCHA-SANTOS, G.; BARBIER E. and BORDIGNON M.O. Sweet trap: Boa constrictor (Serpentes: Boidae) preying on passerines on Cecropia pachystachya (Urticales: Cecropiaceae) in fruiting period. Biota Neotropica. 14(2): e20140003. http://dx.doi.org/10.1590/10.1590/1676-06032014000314

\begin{abstract}
Fruits of trumpet tree (Cecropia spp.) attract different species of birds and mammals. Boas (Boa constrictor) are sit-and-wait strategists, able to choose to ambush in microhabitats that are frequently visited by prey. We have seen two events of predation of passerines (Pitangus sulphuratus, Turdus rufiventris) by boas on the same trumpet tree (Cecropia pachystachya) in a remnant of Cerrado, in the city of Campo Grande/MS. These reports may be evidence of strategic association of boas to trumpet trees, considering the density of snakes recorded on the tree and the constant visits by potential prey during fruiting periods. Besides encouraging a more detailed investigation on the strategies of predation by boas, our records constitute relevant information about the snake natural history.
\end{abstract}

Keywords: ambush predators, boa, Pitangus sulphuratus, sit-and-wait, trumpet tree, Turdus rufiventris.

ROCHA-SANTOS, G.; BARBIER E. and BORDIGNON M.O. Doce armadilha: Boa constrictor (Serpentes: Boidae) predando passeriformes sobre Cecropia pachystachya (Urticales: Cecropiaceae) em período de frutificação. Biota Neotropica. 14(2): e20140003. http://dx.doi.org/10.1590/10.1590/167606032014000314

Resumo: Frutos de embaúba (Cecropia spp.) atraem diversas espécies de aves e mamíferos. Jiboias (Boa constrictor) são estrategistas senta-espera, capazes de selecionar micro-habitats que são frequentemente visitados por presas. Nós presenciamos dois eventos de predação de passeriformes (Pitangus sulphuratus, Turdus rufiventris) por jiboias sobre uma mesma embaúba (Cecropia pachystachya) em um remanescente de Cerrado, localizado na cidade de Campo Grande/MS. Esses relatos podem ser indícios de associações estratégicas das jiboias às embaúbas, considerando a densidade de serpentes na árvore e a constante visitação de presas potenciais durante os períodos de frutificação. Além de estimular uma investigação mais detalhada sobre as estratégias de predação das jiboias, esses registros constituem informações relevantes sobre sua história natural.

Palavras-chave: Embaúba, jiboia, Pitangus sulphuratus, predadores de emboscada, senta-espera, Turdus rufiventris.

\section{Introduction}

Sit-and-wait predators remain still for long periods of time, awaiting for prey within the range of their attacks (O'Brien et al. 1990). The choice of locations for ambushing can be determinant of the successful capture of prey, and some snakes (e.g., Boa constrictor Linnaeus, 1758; Crotalus horridus Linnaeus, 1758; Echis coloratus Günther, 1878; Epicrates inornatus (Reinhardt, 1843); Gloydius shedaoensis (Zhao, 1979)), increase their chances by selecting microhabitats that are frequently visited by prey (Greene 1983, Rodriguez \& Reagan 1984, Rodríguez-Durán 1996, Shine \& Li-Xin 2002, Clark 2004, Tsairi \& Bouskila 2004).
Trumpet trees (Cecropia spp.) are fast growing pioneers, associated mainly to secondary forests (Lorenzi 1992, Santos 2000), found throughout the Neotropical area, from the south of Mexico to the north of Argentina (Franco Rosselli 1997). They can reach up to 22 meters (Sposito \& Santos 2001) and have long fruiting periods (up to 12 months; see Ferraz et al. 1999) and attract several omnivore and frugivorous species, including passerines (Oniki et al. 1994, Chatellenaz 2008), galliforms (Mikich 2002), parrots (Ragusa-Netto \& Fecchio 2006), marmosets (Passamani \& Rylands 2000), bats (Lobova et al. 2003) and coatis (Alves-Costa et al. 2004).

Boas (B. constrictor) are robust snakes that can reach up to $300 \mathrm{~cm}$ of total lenght (see Norman 1994, Marques et al. 2005). 
They are present in the Neotropical area, exploring various vegetation types, such as rainforests, savannas and wetlands (Henderson et al. 1995). They are sit-and-wait strategists (Greene 1983) capable of detecting prey, probably through the association of visual, thermal and chemical stimuli (Scartozzoni \& Molina 2004). They have semi-arboreal habits and feed efficiently both in terrestrial and arboreal environments (Pizzatto et al. 2009). There are several published records on the consumption of birds (Boback 2005, Begoti \& Filho 2012), amphibians (Pizzatto et al. 2009), mammals (Ferrari et al. 2004, Cisneros-Heredia et al. 2005, Sorrell et al. 2011) and reptiles (Quick et al. 2005) by boas, obtained through direct observations or stomach content analysis.

We record here the predation of passerines by boas $(B$. constrictor) in a same fruiting trumpet tree (Cecropia pachystachya Trécul).

\section{Material and Methods}

The predatory behavior of boas was occasionally observed and recorded on two consecutive days during fieldwork in a Cerrado remnant of 50 ha belonging to Private Natural Heritage Reserve, Universidade Federal de Mato Grosso do Sul (RPPN/UFMS), Campo Grande, Brazil (20³0'18.99" S, $\left.54^{\circ} 36^{\prime} 49.97^{\prime \prime} \mathrm{W}\right)$. The reserve is located in an urban area, which is surrounded by boulevards and buildings of the UFMS campus. Vegetation type in the reserve is classified as "cerradão" composed by trees reaching 15-18 m tall, smaller trees, shrubs, and herbaceous plants (Assunção et al. 2011).

\section{Results and Discussion}

We witnessed two events of predation of passerines by boas on a fruiting trumpet tree (C. pachystachya). On 01/31/2013, at 09:47 a.m. $\left(28^{\circ} \mathrm{C}\right)$, we observed the capture of a Rufous-bellied Thrush (Turdus rufiventris Vieillot, 1818) by a boa (individual 1) that had the body partially aligned on the branch of a $8 \mathrm{~m}$ trumpet tree (except by the tail, which remained coiled on the branch) (Figure 1a). The Rufous-bellied Thrush landed on the branch in which the snake was positioned $(<50 \mathrm{~cm}$ from the snake), probably in search of fruit, and was instantly captured and constricted. Then, the snake touched the bird with the labial scales, inspecting it, and started ingesting by the bird's head. Ingestion lasted about $14 \mathrm{~min}$, and the snake returned to its initial position (partially aligned on the branch). At the same time, we spotted two other snakes (individuals 2 and 3 ) positioned on parallel branches, summing up three individuals foraging on that same tree. Individual 1 was located about 50 $\mathrm{cm}$ from individual 2, and individual 3 was positioned $1.5 \mathrm{~m}$ away from 1 and $2 \mathrm{~m}$ away from the individual 2 .

The next morning (02/01/2013), we observed three snakes in the same positions, probably the same individuals sighted in the previous day. At 8:07 a.m. $\left(29^{\circ} \mathrm{C}\right)$ we observe another Rufousbellied Thrush landing on the tree, on a branch near individual $2(<50 \mathrm{~cm}$ from the snake). However, in this event, this bird managed to dodge the attack, escaping capture. Three minutes later we recorded the capture of a Great Kiskadee (Pitangus sulphuratus (Linnaeus, 1766)), by individual 3 (Figure 1b). This event was similar to predation described earlier that morning, with the exception of the time the snake spent eating the bird (19min). After the events of predation, we observed other $C$. pachystachya in the study area, but no snakes were observed on them. No interactions among the snakes were observed.
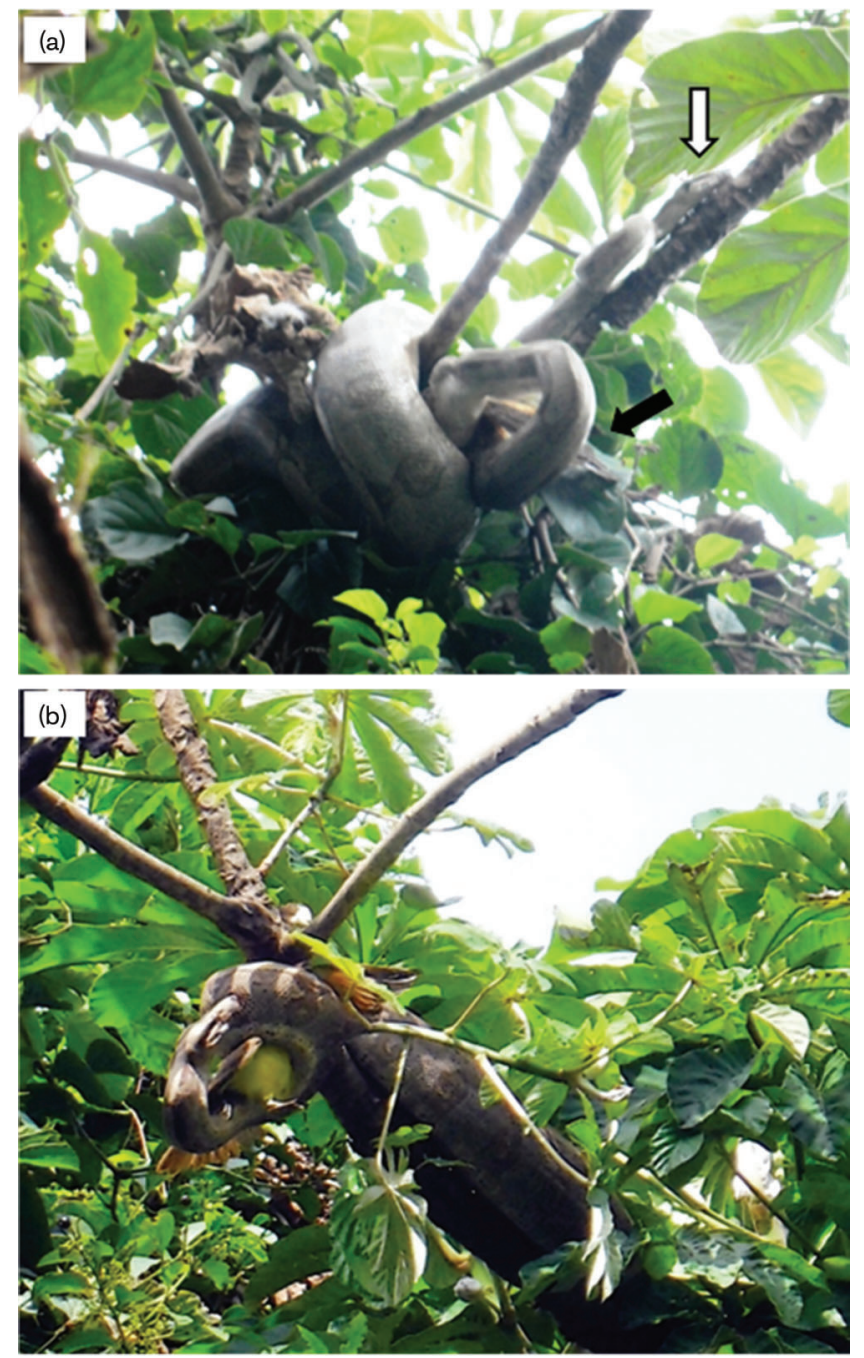

Figure 1. a) Boa constrictor (individual 1) predating Rufous-bellied Thrush (Turdus rufiventris) on a trumpet tree (Cecropia pachystachya). The black arrow indicates the bird's wing and the white arrow points out a conspecific (individual 2) on a parallel branch. b) Boa (individual 3 ) at the time of constriction of a Great Kiskadee (Pitangus sulphuratus) on the same trumpet tree as the other two. Picture: Gilson da Rocha Santos.

Fruits of $C$. pachystachya are used as food resource by many birds (e.g., Ragusa-Neto 2004, Ragusa-Netto \& Fecchio 2006, Chatellenaz 2008), including those belonging to the genus Turdus and Pitangus (Oniki et al. 1994). Published data on the diet of boas show a high proportion of passerine birds (e.g., Boback 2005, Quick et al. 2005). In addition to the T. rufiventris and $P$. sulphuratus recorded in the predation events we also observed Trogon curucui Linnaeus, 1766 feeding on the fruits of the $C$. pachystachya, but in branches farther from the snakes. Moreover, a primate, potential prey of boas, Callithrix penicillata (É. Geoffroy, 1812), has also being observed visiting trumpet trees (Rocha-Santos, G., pers. obs.).

Trophic interactions may influence the distribution and density of a predator, directly affecting their behavior and habitat use (Slip \& Shine 1988). The frequent visitation of trumpet trees by boas' potential preys, together with our records of successful predation and aggregation of the snakes on the tree, suggest that boas may be selecting C. pachystachya as ambushing habitat. Some snakes, including $B$. constrictor 
(Boidae), Crotalus horridus, E. coloratus (Viperidae) may use chemical signals and ultraviolet traces left by prey and thus track favorable places for ambushing (Sillman et al. 2001, Clark 2004, Tsairi \& Bouskila 2004, Scartozzoni \& Molina 2004). Gloydius shedaoensis (Viperidae), for example, is able to select trees with high visitation rates of birds (Shine \& Li-Xin 2002), while E. inornatus (Boidae) groups in cave entrances with large density of bats (see Rodriguez \& Reagan 1984, RodríguezDurán 1996).

Favorable locations for ambushes can also be selected through chemical cues left by snakes of the same species (e.g., C. horridus), which succeeded in capturing prey (Clark 2007). Boas are able to recognize chemical signals and discriminate the age of other individuals, apparently in the context of partner selection (Gabirot et al. 2012). But it is possible that, as $C$. horridus (see Clark 2007), they also use these chemical clues, and/or visual signals, to detect conspecifics in areas with higher food availability.

Obviously, the assumptions mentioned are not mutually exclusive and the mechanisms of selection of sites for ambushes may be more complex, involving other factors such as previous experiences of success, positive relationships of perception of the predator instead of the prey and ease of capture (Shine \& Li-Xin 2002, Clark 2004). However, regardless of the mechanisms of selection and screening, our data may still be evidence of strategic association of boas to trumpet trees, considering the density of these snakes and constant visits from potential prey during periods of fruiting.

\section{Acknowledgements}

To CAPES (Coordenação de Aperfeiçoamento de Pessoal de Nivel Superior) for granting the scholarship for the first two authors.

\section{References}

ALVES-COSTA, C.P., FONSECA, G.A.B., \& CHRISTÓFARO, C. 2004. Variation in the diet of the brown-nosed coati (Nasua nasua) in southeastern Brazil. J. Mammal. 85(3):478-482.

ASSUNÇÃO, V.A., GUGLIERI-CAPORAL, A. \& SARTORI, A.L.B. 2011. Florística do estrato herbáceo de um remanescente cerradão em Campo Grande, Mato Grosso do Sul, Brasil. Hoehnea 38(2):281-288.

BEGOTTI, R.A. \& FILHO, A.M. 2012. Fatal attack on an adult Chestnut-fronted Macaw Ara severus by a Boa constrictor in the brazilian Amazon. Cotinga 34:106-107.

BOBACK, S.M. 2005. Natural history and conservation of island boas (Boa constrictor) in Belize. Copeia 2005(4):880-885.

CHATELlENAZ, M.L. 2008. Diet of the Grayish Saltator (Saltator coerulescens) in northeastern Argentina. Ornitol. Neotrop. 19(1):617-625.

CISNEROS-HEREDIA, D.F., LEÓN-REYES, A. \& SEGER, S. 2005. Boa constrictor predation on a Titi monkey, Callicebus discolor. Neotrop. Primates 13(3):11-12.

CLARK, R.W. 2004. Feeding experience modifies the assessment of ambush sites by the Timber Rattlesnake, a sit-and-wait predator. Ethology 110(6):471-483.

CLARK, R.W. 2007. Public information for solitary foragers: timber rattlesnakes use conspecific chemical cues to select ambush sites. Behav. Ecol. 18(2):487-490.

FERRARI, S.F., PEREIRA, W.L.A., SANTOS, R.R. \& VEIGA, L.M. 2004. Fatal attack of a Boa constrictor on a Bearded Saki (Chiropotes satanas utahicki ). Folia Primatol. 75(2):111-113.

FERRAZ, D.K., ARTES, R., MANTOVANI, W. \& MAGALHÃES, L.M. 1999. Fenologia de árvores em fragmento de mata em São
Paulo, SP. Braz. J. Biol. 59(2):305-317.

FRANCO-ROSELLI, P. 1997. Distribution patterns of Cecropia (Cecropiaceae): a panbiogeographic analisis. Caldasia 19(1-2):285296.

GABIROT, M., PICERNO, P., VALENCIA, J., LOPEZ, P. \& MARTIN, J. 2012. Chemosensory age discrimination in the snake Boa constrictor (Serpentes: Boidae). Ver. Biol. Trop. 60(4):16031611.

GREENE, H.W. 1983. Boa constrictor (boa, béquer, boa constrictor). In Costa Rican Natural History (D.H. Janzen, ed.). University of Chicago Press, Chicago, p.380-382.

HENDERSON, R.W., MICUCCI, T.W.P., PUORTO, G. \& BOURGEOIS, R.W. 1995. Ecological correlates and patterns in the distribution of Neotropical boines (Serpentes: Boidae): a preliminary assessment. Herpetol. Nat. Hist. 3(1):15-27.

LOBOVA, T.A., MORI, S.A., BLANCHARD, F., PECKHAM, H. \& CHARLES-DOMINIQUE, P. 2003. Cecropia as a food resource for bats in French Guiana and the significance of fruit structure in seed dispersal and longevity. Am. J. Bot. 90(3):388-403.

LORENZI, H. 1992. Árvores brasileiras: manual de identificação e cultivo de plantas arbóreas nativas do Brasil. Editora Plantarum, Nova Odessa.

MARQUES, O.AV., ETEROVIC, A., STRÜSSMANN, C. \& SAZIMA, I. 2005. Serpente do Pantanal: guia ilustrado. Editora Holos, Ribeirão Preto.

MIKICH, A.B. 2002. A dieta frugívora de Penelope superciliaris (Cracidae) em remanescentes de florestas estacional semidecidual no centro-oeste do Paraná, Brasil e sua relação com Euterpe edulis (Arecaceae). Ararajuba 10(2):207-217.

NORMAN, D.R. 1994. Anfibios y reptiles del Chaco Paraguayo Tomo I. University of Texas Press, San José.

O'BRIEN, W.J., BROWMAN, H.I. \& EVANS, B.I. 1990. Search strategies of foraging animals. Am. Sci. 78(2):152-150.

ONIKI, Y., JÚNIOR, T.A.M., SCOPEL, E.T. \& WILLIS, E.O. 1994. Bird use of Cecropia (Cecropiaceae) and nearby trees in Espirito Santo state, Brazil. Ornitol. Neotrop. 5(2):109-114.

PASSAMANI, M. \& RYLANDS, A B. 2000. Feeding behavior of Geoffroy's marmoset (Callithrix geoffroyi) in an atlantic forest fragment of South-eastern Brazil. Primates 41(1):27-38.

PIZZATTO, L., MARQUES, O.A. \& FACURE, K. 2009. Food habits of Brazilian boid snakes: overview and new data, with special reference to Corallus hortulanus. Amphibia-Reptilia 30(4):533544.

QUICK, J.S., REINERT, H.K., DE CUBA, E.R \& ODUM, R.A. 2005. Recent occurrence and dietary habits of Boa constrictor on Aruba, Dutch West Indies. J. Herpetol. 39(2):304-307.

RAGUSA-NETTO, J. \& FECCHIO, A. 2006. Plant food resources and the diet of a parrot community in a gallery forest of the southern Pantanal (Brazil). Braz. J. Biol. 66(4):1021-1032.

RAGUSA-NETTO, J. 2004. Flowers, fruits and the abundance of the Yellow-chevroned parakeet (Brotogeris chiriri) at a gallery forest in the South Pantanal (Brazil). Braz. J. Biol. 64(4):867877.

RODRIGUEZ, G.A. \& REAGAN, D.P. 1984. Bat predation by the Puerto Rican Boa, Epicrates inornatus. Copéia 1984(1):219220.

RODRÍGUEZ-DURÁN, A. 1996. Foraging ecology of the Puerto Rican Boa (Epicrates inornatus): bat predation, carrion feeding, and piracy. J. Herpetol. 30(4): 533-536.

SANTOS, F.A.M. 2000. Growth and leaf demography of two Cecropia species. Rev. Bras. Bot. 23(2):133-141.

SCARTOZZONI, R.R. \& MOLINA, F.B. 2004. Comportamento Alimentar de Boa constrictor, Epicrates cenchria e Corallus hortulanus (Serpentes: Boidae) em Cativeiro. Rev. Etol. 6(1):2531.

SHINE, R. \& LI-XIN, S. 2002. Arboreal ambush site selection by pitvipers Gloydius shedaoensis. Anim. Behav. 63(3):565-576.

SILLMAN, A.J., JOHNSON, J.L. \& LOEW, E.R. 2001. Retinal 
photoreceptors and visual pigments in Boa constrictor imperator. J. Exp. Zool. 290(4):359-365.

SLIP, D.J. \& SHINE, R. 1988. Feeding habits of the Diamond Python, Morelia s. spilota: ambush predation by a boid snake. J. Herpetol. 22(3):323-330.

SORRELL, G.G., BOBACK, S.M., REED, R.N., GREEN, S., MONTGOMERY, C.E., DE SOUZA L.S \& CHIARAVIGLIO,
M. 2011. Boa constrictor - foraging behavior. Herpetol. Rev. 42(2):281

SPOSITO, T.C. \& SANTOS, F.A.M. 2001. Scaling of stem and crown in eight Cecropia (Cecropiaceae) species of Brazil. Am. J. Bot. 88(5):939-949.

TSAIRI, H. \& BOUSKILA, A. 2004. Ambush site selection of a desert snake (Echis coloratus) at an oasis. Herpetologica 60(1):13-23. 